\title{
The Relation between Symptoms of Computer Vision Syndrome and Visual Display Terminal Utilization
}

\section{Hubungan Gejala Computer Vision Syndrome dengan Penggunaan Visual Display Terminal}

\author{
Rozanna Fithri Nadhiva, Mulyono \\ Department of Occupational Safety and Health, Faculty of Public Health, Universitas Airlangga \\ Campus C Mulyorejo, Surabaya, East Java, 60115 Indonesia
}

\begin{abstract}
Introduction: The increased use of computers in the era of technological advances had an impact on the eye health called Computer Vision Syndrome (CVS), a compound eye problem caused by computer use. Almost every job could not be separated from the use of computers. Based on data from World Health Organization (WHO) in 2014, the incidence of asthenopia (eye fatigue) ranged from $40 \%$ to $90 \%$. This research aimed to determine the relationship between symptoms of Computer Vision Syndrome and Visual Display Terminal utilization. Methods: This research was a quantitative with analytic survey method. Based on the data collection method, this research included as observational research type. This research was conducted with cross-sectional study design. Data collection was carried out with doctor's diagnosis guidelines, interviews, measurement using questionnaires, and observation. The population was 47 permanent workers and the sample taken was 42 respondents from the design division workers. The sampling technique used simple random sampling. The variables in this research were age, working period, distance to VDT, and general lighting intensity. Results: This research showed that the factors associated with symptoms of Computer Vision Syndrome were working period and eye distance to VDT. Conclusion: The longer the working period and the more distance between the eye and the VDT, the more symptoms of VDT would be .
\end{abstract}

Keywords: computer use, symptoms of computer vision syndrome, visual display terminal

\section{ABSTRAK}

Pendahuluan: Peningkatan penggunaan komputer di era kemajuan teknologi memberikan dampak kesehatan pada mata yang disebut dengan sindroma gangguan mata, merupakan masalah mata majemuk yang disebabkan oleh penggunaan komputer. Hampir setiap pekerjaan tidak lepas dari penggunaan komputer. Berdasarkan data World Health Organization (WHO) pada tahun 2014 angka kejadian astenopia (kelelahan mata) berkisar 40\% hingga 90\%. Penelitian ini bertujuan untuk mengetahui hubungan antara gejala Computer Vision Syndrome dengan penggunaan komputer. Metode: Penelitian ini bersifat kuantitatif dengan metode survey analitik. Berdasarkan metode pengumpulan data penelitian ini termasuk jenis penelitian observasional. Penelitian ini dilakukan dengan jenis desain studi cross sectional. Pengumpulan data dilakukan dengan pedoman diagnosis dokter, wawancara, pengukuran dengan kuesioner, dan observasi. Jumlah populasi adalah 47 pekerja tetap dan besar sampel berjumlah 42 responden pekerja divisi desain. Teknik pengambilan sampel menggunakan simple random sampling. Variabel pada penelitian ini adalah usia, masa kerja, jarak mata terhadap VDT, dan intensitas pencahayaan umum. Hasil: Penelitian ini menunjukan bahwa faktor yang berhubungan dengan gejala Computer Vision Syndrome adalah masa kerja dan jarak mata terhadap VDT. Simpulan: Semakin lama masa kerja dan semakin jauh jarak antara mata dan VDT, maka semakin menimbulkan gejala Computer Vision Syndrome.

Kata kunci: gejala computer vision syndrome, penggunaan komputer, visual display terminal

\section{Corresponding Author:}

Rozanna Fithri Nadhiva

Email: rozanna.fithri.nadhiva-2016@fkm.unair.ac.id

Telephone: +6285749286204

\section{INTRODUCTION}

Technological advances have been developing for more than 20 years, one of which is the invention of computers. The use of computers and digital electronic devices has become an activity among modern society. The use of electronic screens is no longer limited because watching can be done 
by using a desktop computer at workplace (Thatte and Choudhary, 2020). Computer becomes a very important tool when working because it gives faster jobs and results. According to Irmayani et al. (2020), almost all fields of work today use computers as a tool to facilitate work. There are around 100 million people use computers in their daily work. Excessive use of computers can cause disease not only in the eyes, but also on the head, or limbs (Permana et al., 2015).

Normal eye can see focus on a well-angled image against a background of color and good contrast between the background and the text. How to see an image on a computer screen is different from seeing an image printed on paper, because on a computer screen, it uses a collection of tiny dots called pixels. Each pixel emits a bright light in the center but gradually darkens at the edges. This causes the normal eye to be unable to focus on seeing the image, but instead focuses on a point behind the screen which is known as the resting point of accommodation (RPA) or "dark focus". Continuous eye work causes CVS symptoms (Pratiwi et al., 2020).

American Optometric Association (AOA) defines the occurence of CVS as a problem caused by the use of computer, tablet, e-reader, handphone and other electronics devices if used continuously for a long time causing discomfort in eyes and vision. Globally, people suffering from CVS range from nearly 60 million and are expected to increase by millions of cases each year (Ranasinghe et al., 2016).

Survey data from the Indonesian Internet Service Providers Association (APJII) in 2016 revealed that the average internet access in Indonesia using computers was 2.2 million people or 1.7 percent. Workers or entrepreneurs who have a computer were 82.2 million people or $62 \%$ in Indonesia (Asnifatima et al., 2017).

Based on the data from Word Health Organization (WHO) in 2014, the incidence of asthenopia (eye fatigue) ranged from $40 \%$ to $90 \%$. Based on the worldwide internet used data (2016), the number of computer users in the world was $88 \%$ in $2013,72 \%$ in 2014 , and $68 \%$ in 2015 and $60 \%$ in 2016 (Irma et al., 2019).

Along with the increasing use of computers, the number of sufferers of visual complaints grouped together in CVS terms also increases, such as tension and fatigue in the eyes, burning sensation, irritation, redness, haze, dry eyes, and so on. CVS symptoms are grouped into four major groups, namely Astenopi (tense, tired and sore eyes), associated with the surface of eyeball (dry, watery eyes, irritation, problems with contact lens use), vision (blurred vision, slow in changing focus, double vision, presbyopia), extraocular (pain in the shoulders, arthritis, muscle injury, sloping neck, pinched nerves). According to Cole \& Collins, the above symptoms are a combination of vision problems, poor working conditions, and wrong habits (Nopriadi et al., 2019).

Based on research conducted by Tubtimhin and Puthaburi (2019), it was found that the population experiencing very high CVS by $99.5 \%$ with a CI value of 96.8. The classification carried out in the CVS group found the occurred problem of an ocular surface problems was $94.7 \%$ with a CI value of 90.1 , eyes that were tense and tired eyes was $95.3 \%$ with a CI value of 90.9 , complaints of blurred vision was $78.1 \%$ with a CI value of 71.1 , and multiple vision was $42 \%$ with a CI value of 34.5 . The average CVS occurred occasionally with the severity included in the minor category. Most CVS occurred occasionally with severity included in the minor category. However, many cases showed lighting sensitivity by $14.2 \%(95 \% \mathrm{CI}: 8.5,21.7)$.

According to Shantakumari (2014), the most common CVS complaints reported among computer users in students at Ajman, the United Emirate were headaches by $53.3 \%$, sensation burns in the eyes by $54.8 \%$ and tired eyes by $48 \%$. Research in Malaysia obtained that as much as $42.9 \%$ obtained risk of developing CVS due to continuous computer use for more than 2 hours without taking any breaks and $20 \%$ using the computer for 4 to 6 hours per day.

Meanwhile, based on research conducted by the Faculty of Nursing at Syiah Kuala University (FKep Unsyiah) about the symptoms of CVS in 417 respondents obtained $77.7 \%$ respondents experienced symptoms of asthenopia such as tired eyes and $47 \%$ respondents experienced symptoms on the ocular surface such as watery eyes. As much as $50.6 \%$ respondents experienced visual symptoms such as sensitivity to light and $50.2 \%$ of respondents experienced extraocular symptoms such as back pain (Alma and Asniar, 2019).

The purpose of this research was to find and analyze whether there was a relationship between the utilization of Visual Display Terminal (VDT) and the symptoms of Computer Vision Syndrome (CVS) in the design workers at PT PAL Surabaya. 


\section{METHODS}

This research was quantitative with analytic survey method because it aimed to find the relationship between variables and analyzed data. Based on the data collection method, this research included as observational research because there was no treatment or intervention, only by direct observation of the research object or the variables. This research was conducted with cross-sectional study design where the research took place at one time to find out the relationship between variables in the research. The location of this research was carried out in the design division of PT PAL Surabaya. This research was conducted in March 2020. This study has obtained ethical permission under number 33/EA/KEPK/2020.

The population in this research were all permanent workers in the design division who used VDT computers in PT PAL Surabaya consisting of 47 workers. Meanwhile, the sample was taken using simple random sampling method obtaining 42 workers who used VDT computers in the units mentioned above. Data collection was done by using primary and secondary data.

The tools used in this research were the doctor's diagnosis guidelines, interviews, questionnaires, measurements consisting of measurement of eye distance to VDT using a rollmeter, measurement of general lighting intensity using luxmeter and office stationery.

Analysis of data used was software Statistical Package for Social Sciences (SPSS). There were two kinds of analyzes applied in this research, namely univariate and bivariate analysis. Univariate analysis was performed by displaying the frequency distribution and percentage of each variables, while bivariate analysis was carried out in order to find out the relationship between variables of worker factors, work device factors and work environment factors with the symptoms of computer vision syndrome using the chi-square test with a significant value of $95 \%$ or $\mathrm{a}=0.05$.

\section{RESULTS}

The result of this research was obtained by using worker factors (age, work period, Eye Distance to VDT) and General Lighting Intensity.

\section{Worker Factors}

Age

Based on Table 1, from a total of 42 respondents, most of them were 26-45 years old by 19 respondents (42.8). Whereas, in the 17-25 years old category, there were 11 respondents (26.2) and in the 46-65 years old category, there were 12 respondents $(31 \%)$.

\section{Working Period}

The work period was divided into 2 categories namely $<10$ years and $\geq 10$ years. In Table 3 , among the total of 42 respondents, the majority of the workers have been working for $<10$ years by 23 respondents $(54.8 \%)$, while in the $\geq 10$ years category, there were, 19 respondents $(45.2 \%)$.

\section{Eye Distance to VDT}

Eye distance to VDT was divided into optimal and non-optimal. The optimal distance is $50-60 \mathrm{~cm}$, while the non-optimal distance is $<50$ and $>60 \mathrm{~cm}$. Based on Table 3, from the total respondents of 42 people, there were 16 respondents $(38.1 \%)$ which had a distance of 50-60 cm. Meanwhile, in the $<50$ and $>60 \mathrm{~cm}$ categories, there were 26 respondents $(61.9 \%)$.

Table 1. The Distribution of Age in the Design Division of PT PAL Surabaya, 2020

\begin{tabular}{ccc}
\hline \multirow{2}{*}{ Age } & \multicolumn{2}{c}{ Total Respondents } \\
\cline { 2 - 3 } & Frequency (n) & Percentage (\%) \\
\hline $17-25$ years & 11 & 26.2 \\
$26-45$ years & 19 & 42.8 \\
$46-65$ years & 12 & 31.0 \\
\hline Total & 42 & 100 \\
\hline
\end{tabular}

Table 2.The Distribution of Working Period in the Design Division of PT PAL Surabaya, 2020

\begin{tabular}{ccc}
\hline \multirow{2}{*}{ Working Period } & \multicolumn{2}{c}{ Total Respondents } \\
\cline { 2 - 3 } & Frequency (n) & Percentage (\%) \\
\hline$<10$ years & 23 & 54.8 \\
$\geq 10$ years & 19 & 45.2 \\
\hline Total & 42 & 100 \\
\hline
\end{tabular}




\section{Environmental Factor}

\section{General Lighting Intensity}

General lighting category was divided into ideal and non-ideal. According to the Regulation of Minister of Manpower 2018 Number 5 concerning occupational safety and health in the work environment, the standard of lighting intensity for types of office work that requires precision can be categorized as ideal if $\geq 300$ lux, while non ideal if $<300$ lux. Based on Table 4, it showed that most of general lighting intensity $<300$ lux in 3 rooms as many as 40 respondents (95.2\%). Meanwhile, the category $\geq 300$ lux in 1 room were 2 respondents $(4.8 \%)$.

Relation between Age and Computer Vision Syndrome (CVS) Symptoms in PT PAL Surabaya

Table 5 showed that out of 11 respondents aged 17-25 years, $6(37.5 \%)$ respondents experienced CVS symptoms. In the age category of 26-45 years old, out of 19 respondents, there were 6 respondents (37.5\%) who experienced CVS symptoms. Whereas in the age category of 46-65 years old, there were 4 respondents $(25 \%)$ out of 12 respondents who experienced CVS symptoms. As a result of the chisquare statistical test, the age variable with $p=0.431$

Table 3. The Distribution of Eye Distance to VDT in the Design Division of PT PAL Surabaya, 2020

\begin{tabular}{|c|c|c|}
\hline \multirow{2}{*}{$\begin{array}{c}\text { Eye Distance to } \\
\text { VDT }\end{array}$} & \multicolumn{2}{|c|}{ Total Respondents } \\
\hline & Frequency (n) & Percentage (\%) \\
\hline $\begin{array}{l}50-60 \mathrm{~cm} \\
(\text { Optimal) }\end{array}$ & 16 & 38.1 \\
\hline $\begin{array}{l}<50 \text { and }>60 \mathrm{~cm} \\
(\text { Non-Optimal) }\end{array}$ & 26 & 61.9 \\
\hline Total & 42 & 100 \\
\hline
\end{tabular}

Table 4. The Distribution of General Lighting Intensity in the Design Division of PT PAL Surabaya, 2020

\begin{tabular}{ccc}
\hline General & \multicolumn{2}{c}{ Total Respondents } \\
Lighting Intensity & Frequency (n) & Percentage (\%) \\
$\geq 300$ lux (Ideal) & 2 & 4.80 \\
$<300$ lux (Non- & 40 & 95.2 \\
Ideal) & & 100 \\
\hline Total & 42 &
\end{tabular}

was obtained, so there was no relation with CVS symptoms in PT PAL Surabaya design division.

Relation between Working Period and Computer Vision Syndrome (CVS) Symptoms in PT PAL Surabaya

The working period category in Table 6 showed that there were 4 respondents $(25 \%)$ out of the 23 respondents who had a working period of $<10$ years experiencing symptoms of CVS. Meanwhile, the 19 respondents who had a working period $\geq 10$ years of as many as $12(75 \%)$ of respondents experienced symptoms of CVS. Based on the results of the chisquare statistical test, it was found that the variable of working period obtained a value of $\mathrm{p}=0.002$, which means that there was a relationship with the symptoms of CVS in the design division of PT PAL Surabaya.

\section{The Relation between Eye Distance and VDT with Computer Vision Syndrome (CVS) Symptoms in PT PAL Surabaya}

The optimal category of the eye distance to VDT is $50-60 \mathrm{~cm}$, while the non-optimal category of the eye distance to VDT is $<50$ and $>60 \mathrm{~cm}$. Based on Table 7, it showed that out of the 16 respondents who had an eye distance to VDT $50-60 \mathrm{~cm}$, as many as $2(12.5 \%)$ respondents experienced symptoms of CVS. Whereas for 26 respondents who had an eye distance to VDT $<50$ and $>60 \mathrm{~cm}$, as many as 14

Table 5. The Relation between Age and Computer Vision Syndrome (CVS) Symptoms in PT PAL Surabaya, 2020

\begin{tabular}{|c|c|c|c|c|c|c|c|}
\hline \multirow{3}{*}{$\begin{array}{l}\begin{array}{l}\mathbf{A} \quad \mathbf{g} \\
\text { (Yeears) }\end{array}\end{array}$} & \multicolumn{4}{|c|}{ CVS Symptoms } & \multirow{2}{*}{\multicolumn{2}{|c|}{ Total }} & \multirow{3}{*}{$\begin{array}{c}\rho \\
\text { Value }\end{array}$} \\
\hline & \multicolumn{2}{|c|}{ CVS } & \multicolumn{2}{|c|}{ Non CVS } & & & \\
\hline & $\mathbf{n}$ & $\%$ & n & $\%$ & $\mathbf{N}$ & $\%$ & \\
\hline $17-25$ & 6 & 37.5 & 5 & 19.2 & 11 & 100 & \\
\hline $26-45$ & 6 & 37.5 & 13 & 50.0 & 19 & 100 & 0.431 \\
\hline $46-65$ & 4 & 25.0 & 8 & 30.8 & 12 & 100 & \\
\hline
\end{tabular}

Table 6. The Relation between Working Period and Computer Vision Syndrome (CVS) Symptoms in PT PAL Surabaya, 2020

\begin{tabular}{|c|c|c|c|c|c|c|c|}
\hline \multirow{3}{*}{$\begin{array}{c}\text { Working } \\
\text { Period }\end{array}$} & \multicolumn{4}{|c|}{ CVS Symptoms } & \multirow{2}{*}{\multicolumn{2}{|c|}{ Total }} & \multirow{3}{*}{$\begin{array}{c}\rho \\
\text { Value }\end{array}$} \\
\hline & \multicolumn{2}{|c|}{ CVS } & \multicolumn{2}{|c|}{ Non CVS } & & & \\
\hline & n & $\%$ & n & $\%$ & $\mathbf{N}$ & $\%$ & \\
\hline$<10$ years & 4 & 25 & 19 & 73.1 & 23 & 100 & \multirow{2}{*}{0.002} \\
\hline$\geq 10$ years & 12 & 75 & 7 & 26.9 & 19 & 100 & \\
\hline
\end{tabular}


Table 7. The Relation between Eye Distance to VDT and Computer Vision Syndrome (CVS) Symptoms in PT PAL Surabaya, 2020

\begin{tabular}{|c|c|c|c|c|c|c|c|}
\hline \multirow{3}{*}{$\begin{array}{l}\text { E y e } \\
\text { Distance } \\
\text { to VDT }\end{array}$} & \multicolumn{4}{|c|}{ CVS Symptoms } & \multirow{2}{*}{\multicolumn{2}{|c|}{ Total }} & \multirow{3}{*}{$\begin{array}{c}\rho \\
\text { Value }\end{array}$} \\
\hline & \multicolumn{2}{|c|}{ CVS } & \multicolumn{2}{|c|}{ Non CVS } & & & \\
\hline & $\mathbf{n}$ & $\%$ & $\mathbf{n}$ & $\%$ & $\mathbf{N}$ & $\%$ & \\
\hline Optimal & 2 & 12.5 & 14 & 53.8 & 16 & 100 & \\
\hline $\begin{array}{c}\text { Non } \\
\text { Optimal }\end{array}$ & 14 & 87.5 & 12 & 46.2 & 26 & 100 & 0.007 \\
\hline
\end{tabular}

Table 8. The Relation between General Lighting Intensity and Computer Vision Syndrome (CVS) Symptoms in PT PAL Surabaya, 2020

\begin{tabular}{|c|c|c|c|c|c|c|c|}
\hline \multirow{3}{*}{$\begin{array}{c}\text { General } \\
\text { Lighting } \\
\text { Intensity }\end{array}$} & \multicolumn{4}{|c|}{ CVS Symptoms } & \multirow{2}{*}{\multicolumn{2}{|c|}{ Total }} & \multirow{3}{*}{$\begin{array}{c}\rho \\
\text { Value }\end{array}$} \\
\hline & \multicolumn{2}{|c|}{ CVS } & \multicolumn{2}{|c|}{ Non CVS } & & & \\
\hline & $\mathbf{n}$ & $\%$ & $\mathbf{n}$ & $\%$ & $\mathbf{N}$ & $\%$ & \\
\hline $\begin{array}{l}\geq 300 \text { lux } \\
\text { (Ideal) }\end{array}$ & 1 & 6.3 & 1 & 3.8 & 2 & 100 & \\
\hline $\begin{array}{c}<300 \text { lux } \\
\text { (Non- } \\
\text { Ideal) }\end{array}$ & 15 & 93.8 & 25 & 96.2 & 40 & 100 & 0.007 \\
\hline
\end{tabular}

(87.8\%) respondents experienced symptoms of CVS. Statistical test results of the eye distance to VDT obtained a value of $\mathrm{p}=0.007$, so it has a relationship with the symptoms of CVS in PT PAL Surabaya design division.

\section{The Relation between General Lighting Intensity and Computer Vision Syndrome (CVS) Symptoms in PT PAL Surabaya}

Table 8 shows that among 2 respondents who worked with general lighting intensity $\geq 300$ lux, $1(6.3 \%)$ respondent experienced CVS symptoms. Meanwhile, for 40 respondents who worked with general lighting intensity of $<300$ lux, 15 (93.8\%) respondents experienced symptoms of CVS. Based on the results of the statistical test of the general lighting intensity variable with a value of $\mathrm{p}=0.623$, there was no relation between general lighting intensity with CVS symptoms in PT PAL Surabaya design division.

\section{DISCUSSION}

\section{Computer Vision Syndrome (CVS)}

According to Lurati (2018), Computer Vision Syndrome is a phenomenon related to the utilization of Visual Display Terminal, has symptoms of eye fatigue, headaches, dry eyes, diplopia, and blurry vision, also often referred to as asthenopia. The first component involves external sensations associated with dry eyes (e.g. burning and irritation) and the second component involves internal symptoms (such as headaches or diplopia). Sari and Himayani (2018) said that the symptoms of CVS that often arises are tense eyes, tired eyes, the slow ability to focus, dry eyes and irritation, and headaches. Physiology explanation of close distance will make eye overaccommodate which results in the overworked ciliary muscles, which manifests in eye fatigue and headaches. The causes of watery eyes and eye irritation are reflected light and shadows formed on the monitor. Placing the monitor at a lower level than the eye can reduce eye irritation. Looking down means that the surface area of the eye is covered by the eyelid, so that unconsciously the eyes will blink more often (Zulaiha et al., 2018).

Workers as the object of research were workers who use computers every day in completing their work. Based on the results of data analysis, it was known that workers who have symptoms of Computer Vision Syndrome (CVS) were 38\% out of 42 workers. The information obtained from the results of the doctor's diagnosis with PT PAL Surabaya design division that the symptoms experienced were headaches, dizziness, insomnia, red eyes, irritation, concentration problems, blurred vision and muscle aches. This is because when someone works by seeing a luminous object on a colored base at close range continuously for a long period of time, the accommodation power decreases. Accommodation involves the work of the sensory and extraocular muscles that cause pupillary shrinkage (miosis), the approach of the point of sight and the convergence of position of the eyeball. A long contraction time can cause spasms of these muscles and will cause pain (Insani, 2018). Enforcement of diagnosis in patients who are exposed to the vision problem due to screen computer is difficult to do, but the pain that is caused can be cured by carrying out the treatment according to the procedure (Evans and Allen, 2016).

\section{Worker Factors}

The worker factors is a personal factor that distinguishes each employee based on their age, working period, and Eye Distance to VDT.

\section{Age}

Age is the length of time that helps a person from birth to the time when the data is collected. 
Based on the results of the study, it shows that workers in the design department of PT PAL Surabaya have varied ages. However, most of them are in the adult age group, which is $26-45$ years old. The youngest age is 23 years and the oldest age is 56 years. According to the Central Statistics Agency (2020), the productive age is the population within the age range 15 - 64 years, so that most workers in the Design section are included in the productive age category.

\section{Working Period}

The working period is the accumulated length of time the worker holds his job in the company. The working period is also a person's experience at work. However, the length of the work period is an activity that a person goes through which can cause boredom and lead to fatigue. Work history that has not had a previous job rotation, with an environment at risk of causing eye fatigue, can cause eye irritation (Sumarno, 2015).

Based on the research results, the working tenure category in the Design section of PT PAL Surabaya has varied tenure. However, most workers have a working period of less than 10 years. The shortest working period is 1 year and the longest working period is 35 years. There are variations in the working period in the Design section due to the employment status of workers. Organic (permanent) workers are likely to have a longer working period than PKWT (fixed-time work agreement) workers. According to Alisah (2016), it was obtained a p-value $<\alpha$ value of 0.05 , namely 0.020 so that Ho was rejected, which means that there was a relationship between working period and CVS complaints on employees of PT Pertamina (Persero) RU VI Balongan - Indramayu in 2015.

\section{Eye Distance to VDT}

The eye distance to the VDT is the distance between the worker's eye and the center of the monitor. According to (Insani, 2018) when workers see a luminous object on a colored base at close range continuously for a certain period of time, it will cause the eye to have to accommodate for a long period of time so that the accommodation capacity decreases. Long contraction time can spasm the eye muscles and will result in pain. Based on the results of the study, the category of eye distance to VDT in the Design section of PT PAL Surabaya, most of the workers were $<50$ and $>60 \mathrm{~cm}$ (not optimal) with an average distance of $64 \mathrm{~cm}$. This is because workers can see objects clearly at a distance, whereas respondents who see computers at close range say that they are used to working at close range because they feel more comfortable. According to Darmaliputra and Dharmadi (2019) research, $79.6 \%$ of respondents who used computers with visibility less than $50 \mathrm{~cm}$ experienced CVS.

\section{Environmental Factor}

The work environment factor examined in this study was the general lighting intensity. General lighting intensity is lighting that illuminates the room evenly.

\section{General Lighting Intensity}

General lighting intensity is lighting that illuminates the workplace area evenly. Based on the research results, it showed that the workers in the design department of PT PAL Surabaya mostly used general lighting intensity $<300$ lux. The required lighting intensity depends on the accuracy of the work being observed. The lighting intensity required in each workplace is determined by the type and nature of the work being performed. The higher the level of accuracy of a job, the greater the need for the required light intensity.

\section{The Relation between Age and Computer Vision Syndrome (CVS) Symptoms in PT PAL Surabaya}

One of the individual factors that can affect the symptoms of computer vision syndrome is age. Computer workstation can be affected by age factors. Users who have young age category understand computer systems better than users who have old age category, because young workers have used computers at school or college. Meanwhile, in the old age category they need supporting tools such as reading glasses to read screens and document sources. The size and legibility of the computer display fonts and icons will be important for this group (Kumar and Kumar, 2017).

Looking at Table 6, it is known that the average age of respondents was $26-45$ years. Chisquare results showed that age was not related to CVS symptoms. According to the researcher's assumptions, this was because most of the ship design workers were male, workers aged under 45 years, were active smokers and were categorized as heavy smokers thus triggering the occurrence of 
early degenerative processes caused by an increase in free radicals in the body which had impact in eye lens. Other than that, there were other factors such as high work demands. Workers under 45 years had high work motivation due to the high demands of living needs to improve better living standards so workers were motivated to get bigger bonuses, and bonuses were in line with worker productivity.

This research was supported by Agbonlahor (2019) on CVS in 215 adult worker respondents in FCT Nigeria. This research focused on a population of adult working class within the age range of 18 years to 35 years in the FCT, office workers or workers who works from home using computer while working. The average age of respondents was $30-35$ years old $(63.3 \%)$ with a minimum age of 18 years old and a maximum age of 35 years old. The results showed that there was no relation between age factors and CVS symptoms with a value of $\mathrm{p}=0.235$.

According to Fradisha (2017), CVS cases reported will increase at the age of $>40$ years. From the results of the research, 29 people experienced CVS and 34 other workers did not experience CVS. Based on the SPSS calculation, the results showed that there was no meaningful relationship between age and CVS as evidenced by the value of $\mathrm{p}=0.432$. This is because the researchers took samples with age criteria $<40$ years, thereby eliminating confounding variables.

\section{The Relation between Working Period and Computer Vision Syndrome (CVS) Symptoms in PT PAL Surabaya}

The working period is the period of time a worker is engaged in the work. Working period is an experience gained by someone in working, but working in a long working period can cause fatigue as well as boredom. Work that does not apply the previous work rotation system to the work environment are at risk of experiencing eye fatigue which results in eye irritation (Naota et al., 2019).

Table 6 shows that the average working period of the respondents was $\geq 10$ years. Chisquare statistical test results found that there was a significant relationship between working period and CVS symptoms. This was because the working period of using a computer had to do with the length of work duration, so the longer the working period of workers, the longer the exposure duration of workers so that it could have a direct impact on eye health. Symptoms that arose due to the use of computers were often ignored by workers, this condition aggravated the incidence of CVS.

This research was supported by research conducted by Lumolos et al. (2016) obtained from the results of statistical tests that the working period affects the vision that CVS incidence occur more frequently in computer user workers who have worked for more than 10 years with a significance of 0.025 . Increasing working hours in front of a computer without taking rest can reduce the ability of accommodation so that it will aggravate the CVS symptoms on computer rental workers in Sario and Malayang Sub-districts of Manado.

According to research conducted by Valentina et al. (2019), it was stated that respondents who work in front of a computer $\geq 6$ years have a 6.2 times higher risk of experiencing CVS. The longer a person uses a computer, the risk of experiencing CVS symptoms such as visual complaints, musculoskeletal, and stress will increase. These symptoms are more common in individuals who have used computers for $>9$ years.

\section{The Relation between Eye Distance to VDT and Computer Vision Syndrome (CVS) Symptoms in PT PAL Surabaya}

According to Sugarindra and Allamsyah (2017), it was stated that the eye has a Resting Point of Accommodation (RPA) which is the point where the eye will focus without a visual stimulus or when in the dark i.e. between $20-37$ inches $(50.8 \mathrm{~cm}-93.98$ $\mathrm{cm})$. The habit of focusing on sight objects at shorter distances from the ideal RPA, such as on computer workers, can trigger stress in the eye. According to the Occupational Safety and Health Association (OSHA) workers using computers must be apart at least 200 inches or around $50 \mathrm{~cm}$. Monitor distances that are too close can cause eye strain, fatigue, and potential for visual disturbances. Ergonomic distance between the monitor screen and computer users ranges from $50 \mathrm{~cm}$ to $60 \mathrm{~cm}$ (Berliana and Rahmayanti, 2017).

Table 6 showed that the average eye distance to VDT $<50 \mathrm{~cm}$ and $>60 \mathrm{~cm}$. Chi-square statistical test results found that there was a significant relation between eye distance to VDT with CVS symptoms. It is in accordance with the main reason of CVS symptoms' occurence, which is the distance that is too close between eyes and monitor so tension happens because of being forced to work in a close distance for a long time, whereas the eye specialize in doing work from specific distance and not too 
close. Based on the results of observations made by researcher, the type of work related to design was a complex work and required accuracy. Type of work related to design used certain software in which there were many numbers such as coding with font size $<12$. This proved that the reason for the eye distance to VDT in respondents was because it was too close. It was also caused by work attitude where respondents who want to lean their forearms against the table because the respondent's chairs did not have arm rest.

This research was in line with Irma's et al. (2019) that stated based on the results of statistic test using chi-square, there was a significant relationship between monitor distance and subjective complaint of eye fatigue on the computer users at PT PLN (Persero) Rayon Soppeng and Rayon Pajalesang District Soppeng with the value of $p=0.000$. Monitors that are too close can cause eye strain, fatigue, and potential for visual disturbances. If the eye sees objects too close for a long time, it will cause ciliary muscle tension, causing fatigue in the eye. When someone works by seeing luminous objects on colored bases at close range continuously for a period of time, it can cause the eye to continuously to be accommodated. The eyes that are continually accommodated will cause eye strain.

\section{The Relation between General Lighting Intensity and Computer Vision Syndrome (CVS) Symptoms in PT PAL Surabaya}

General lighting is a design used to provide lighting in all work areas. Generally, general lighting is installed on permanent ceilings in large workplaces (Tarwaka, 2015). Good lighting according to (Suma'mur, 2013) is lighting that can facilitate workers in doing their jobs clearly without any unnecessary efforts. Well-designed lighting can help make conditions of comfortable work environment and give the impression of a better view as well as a pleasant environment to maintain worker's spirit and help increase productivity. Each job has different lighting intensities depending on the type and characteristic of the work. According to the Minister of Manpower Regulation 2018 Number 5 concerning Occupational Safety and Health (2018), the recommended general lighting for office work that requires precision should be 300 lux meters.

The results of the research of several PT PAL Surabaya's office design rooms had poor lighting with the average of $<300$ lux. Table 8 shows that general lighting did not have a significant relationship with CVS symptoms. Even so in this research, it was found that more workers who had poor lighting did not have CVS symptoms. The results of the analysis of this relationship is different from the existing theories. This was because there were other factors that trigger CVS symptoms such as differences in workload for each worker. In addition, workers also admit that they were used to work in poor lighting conditions.

This research was supported by Putri and Mulyono (2018) that from the results of the study there was no significant relationship between lighting and eye fatigue with a value of $p=1.000$. In the research, it was found that almost all workers who had good or poor lighting had eye fatigue complaints. Symptoms of eye fatigue complaints that are often experienced are eye strain and blurred vision.

\section{CONCLUSION}

Based on the results of the research, it was found that most of the design division workers of PT PAL Surabaya did not experienced CVS symptoms. The longer the working period, and the more distance between eye and the monitor of VDT, the more symptoms of CVS would be.

\section{ACKNOWLEDGEMENTS}

I thank all those who have helped and were involved in this research. The most important is the Design and K3LH division workers in PT PAL Surabaya who have helped with the data collection process. I also want to thank the field supervisors Pak Andri and Pak Eko who have been giving advice of research's technic and time.

\section{REFERENCES}

Agbonlahor, O. (2019). Prevalence and knowledge of Computer Vision Syndrome ( CVS ) among the Working Class Adults in F . C . T . Nigeria. Journal of the Nigerian Optometric Association, 8(12), pp. 49-60.

Alisah, A. H. I. R. (2016). Hubungan Faktor Individu d an Lingkungan Terhadap Keluhan Computer Vision Syndrome. Jurnal Ke Sehatan Masyarakat, 1(4), pp.30-34.

Alma, S., and Asniar. (2019). Faktor Risiko Computer Vision Syndrome pada Mahasiswa Fakultas 
Keperawatan Universitas Syiah Kuala. Jurnal Ilmiah Mahasiswa Fakultas Keperawatan, 4(1), pp.128-135.

Asnifatima, A., Prakoso, I., and Fatimah, A. (2017). Faktor Risiko Keluhan Computer Vision Syndrome (CVS) Pada Operator Warung Internet Di Kecamatan Bojong Gede, Kabupaten Bogor Tahun 2017. Hearty Jurnal Kesehatan Masyarakat, 5(2), pp.1-7.

Berliana, N., and Rahmayanti, F. (2017). Faktor-Faktor Yang Berhubungan Dengan Keluhan Kelelahan Mata Pada Pekerja Pengguna Komputer Di Bank X Kota Bangko. Jurnal Kesehatan Terpadu, 1(2), pp.68-72.

Statistics Indonesia. (2020). Social and Population. Jakarta: Statistics Indonesia.

Darmaliputra, K., and Dharmadi, M. (2019). Gambaran Faktor Risiko Individual Terhadap Kejadian Computer Vision Syndrome Pada Mahasiswa Jurusan Teknologi Informasi Universitas Udayana Tahun 2015. E-Jurnal Medika, 8(1), pp.95-102.

Evans, B. J. W., and Allen, P. M. (2016). Revisión Sistemática de Los Ensayos Controlados Sobre Estrés Visual Utilizando Filtros Intuitivos $\mathrm{O}$ Colorímetros. Journal of Optometry, 9(4), pp.205-218.

Fradisha, M. (2017). Hubungan Durasi Penggunaan Komputer dengan Computer Vision Syndrome pada Karyawan Bank Sinarmas Jakarta. Nexus Kedokteran Komunitas, 6(1), pp.50-61.

Insani, Y. (2018). Hubungan Jarak Mata dan Intensitas Pencahayaan terhadap Computer Vision Syndrome. Jurnal Manajemen Kesehatan Yayasan RS.Dr. Soetomo, 4(2), pp.153-162.

Irma, I., Lestari, I., and Kurniawan, A. R. (2019). Faktor Yang Berhubungan Dengan Keluhan Subjektif Kelelahan Mata Pada Pengguna Komputer. Jurnal Kesehatan Pencerah, 8(1), pp.15-23.

Irmayani, Irawan, B., Pariduri, A. I., and Lubis, A. S. (2020). Hubungan Lama Penggunaan Komputer Dengan Kejadian Computer Vision Syndrome Pada Pegawai Kantor di Rumah Sakit Grandmed Lubuk Pakam. Jurnal Kesmas \& Gizi (JKG), 2(2), pp.114-118.

Kumar, S. M. R. A. J., and Kumar, C. N. (2017). Design of Workstations for Computer Users : A Review Design of Workstations for Computer Users. Iconic Research and Engineering Journals, 1(4), pp.24-34.
Lumolos, M. P., Polii, H., and Marunduh, S. R. (2016). Pengaruh lama paparan dan masa kerja terhadap visus pada pekerja rental komputer di Kecamatan Sario dan Malalayang Kota Manado. Jurnal E-Biomedik, 4(2), pp.1-5.

Lurati, A. R. (2018). Computer Vision Syndrome: Implications for the Occupational Health Nurse. Workplace Health and Safety, 66(2), pp.56-60.

Ministry of Health (2016) Number 48 concerning Occupational Safety and Health Standards in the Office. Jakarta: Ministry of Health.

Naota, S. K., Afni, N., and Moonti, S. (2019). Faktor-faktor yang Berhubungan dengan Gejala Kelelahan Mata pada Operator Komputer di Dinas Tenaga Kerja dan Transmigrasi Provinsi Sulawesi Tengah. Jurnal Kolaboratif Sains, 1(40), pp.268-282.

Nopriadi, N., et al,. (2019). Faktor yang Berhubungan dengan Kejadian Computer Vision Syndrome pada Karyawan Bank. Jurnal Media Kesehatan Masyarakat Indonesia, 15(2), pp.111-119.

Permana, M. A., Koesyanto, H., and Mardiana. (2015). Faktor Yang Berhubungan Dengan Keluhan Computer Vision Syndrome (Cvs) Pada Pekerja Rental Komputer di Wilayah UNNES. Unnes Journal of Public Health., 4(3), pp.48-57.

Pratiwi, A. D., Safitri, A., and Lisnawaty, J. (2020). Faktor Yang Berhubungan Dengan Kejadian Computer Vision Syndrome ( Cvs ) Pada Pegawai PT Media Kita Sejahtera Kendari Factors Related To The Event Of Computer Vision Syndrome (CVS). Jurnal Kesehatan Masyarakat, 7(1), pp.41-47.

Putri, D. W., and Mulyono. (2018). Hubungan Jarak Monitor, Durasi Penggunaan Komputer, Tampilan Layar Monitor, Dan Pencahayaan Dengan Keluhan Kelelahan Mata. The Indonesian Journal of Occupational Safety and Health, 7(1), pp.1-10.

Ranasinghe, P., et.al., (2016). Computer Vision Syndrome among Computer Office Workers in A Developing Country: An Evaluation of Prevalence and Risk Factors. BMC Research Notes, 9(1), pp.1-9.

Sari, F. T. A., and Himayani, R. (2018). Faktor Risiko Terjadinya Computer Vision Syndrome. Medical Journal Of Lampung University, 7(28), pp. 278-282.

Shantakumari, et al. (2014). Computer Use and Visionrelated Problems among University Students in Ajman, United Arab Emirate. Annals 
of Medical and Health Sciences Research, 4(2), pp. 258-263.

Sugarindra, M., and Allamsyah, Z. (2017). Identifikasi interaksi manusia dan komputer berbasis. Jurnal Teknoin, 23(1), pp.63-72.

Suma'mur. (2013). Higiene Perusahaan dan Kesehatan Kerja. CV Sagung Seto.

Sumarno. (2015). Faktor Yang Berhubungan Dengan Kelelahan Mata Operator Komputer Karyawan PT Angkasa Pura II Kota Padang. Jurnal Kesehatan Masyarakat, 5(1), pp.11-15.

Tarwaka. (2015). Ergonomi Industri: Dasar-Dasar Pengetahuan Ergonomi dan Aplikasi di Tempat Kerja. Surakarta: Harapan Press.

Thatte, S., \& Choudhary, R. (2020). The Prevalence of Dry Eye in Young Individuals Exposed to Visual Display Terminal. The Clinical Ophthalmologist Journal, 1(1), pp.15-18.
Tubtimhin, S., \& Puthaburi, N. (2019). Prevalence and Severity of Computer Vision Syndrome of Supporting Staff in Ubon Ratchathani University. Srinagarind Medical Journal, 34(2), pp.173177.

Valentina, D. C. D., Yusran, M., Wahyudo, R., \& Himayani, R. (2019). Faktor Risiko Sindrom Pengelihatan Komputer pada Mahasiswa Jurusan Ilmu Komputer Fakultas Matematika dan Ilmu Pengetahuan Alam Universitas Lampung. JIMKI, 7(2), pp.29-37.

Zulaiha, S., Rachman, I., \& Marisdayana, R. (2018). Pencahayaan, Jarak Monitor, dan Paparan Monitor sebagai Faktor Keluhan Subjektif Computer Vision Syndrome (CVS). Jurnal Fakultas Kesehatan Masyarakat, 12(1), pp. 38-44. 